\title{
Influence of microbial inoculants on soil response to properties with and without straw under different temperature regimes
}

\author{
Shaukat Abro", Xiaohong Tian ${ }^{2 \star}$, Donghai You ${ }^{1}$ Yuling $\mathrm{Ba}^{2}$, Meng $\mathrm{Li}^{2}$, and Faqi $\mathrm{Wu}^{2}$ \\ ${ }^{1}$ College of Resources and Environment, Northwest University, China. \\ ${ }^{2}$ College of Resources and Environment, Open Laboratory for Plant Nutrition and Agricultural Resources and in \\ Northwest of Agriculture Ministry of China, Yangling, 712100 Shaanxi, P. R. China.
}

Accepted 30 July, 2011

\begin{abstract}
A laboratory study was conducted to investigate efficacy of locally produced microbial inoculants with different concentrations on microbial respiration from soils with and without addition of wheat straw incubated at 20 and $25^{\circ} \mathrm{C}$ temperatures for 73 days. The results indicated that the soil microbial community structure and activities were obviously influenced by microbial inoculants. In general, whereas all inoculants levels were successfully established to different extents on the straw, none significantly improved decomposition in either soils or straw amended treatments. Additions of microbial inoculants expedite the decomposition and $\mathrm{CO}_{2}$ evolution process. $\mathrm{CO}_{2}-\mathrm{C}$ emission was regularly determined and results revealed microbial inoculants had little (10\%) while straw addition significantly increased decomposition rates and cumulative $\mathrm{CO}_{2}-\mathrm{C}$ by $39 \%$ in straw amended than controls. Straw addition into soil had significant relationships $(p<0.05)$ with cumulative amounts of $C$; soil organic $\mathrm{C}$, microbial biomass nitrogen. There was highly significant relationship between $\mathrm{CO}_{2}-\mathrm{C}$ emission and incubation period $\left(R^{2}=0.94\right)$. In conclusion, microbial inoculants and straw incorporation will enhance $\mathrm{CO}_{2}-\mathrm{C}$ evolution, soil carbon and microbial biomass, thus improving soil quality.
\end{abstract}

Key words: Microbial inoculants, soil $\mathrm{CO}_{2}-\mathrm{C}$ evolution, decomposition microbial biomass, organic carbon.

\section{INTRODUCTION}

Soil quality, food security and carbon dioxide emissions are largely influenced by Soil organic carbon (SOC) contents (Lal, 2004; Wang et al., 2009). Changes in SOC affect carbon cycle, atmospheric $\mathrm{CO}_{2}$ and climate (Vanhala et al., 2007). Crop straw removal, manure abandonment and field practices with low carbon returns to arable soils have depleted SOC contents (Dalia and Grazina, 2008; Zhang et al., 2008). As often observed in many parts of world, decline in SOC is also an increasing concern in China, especially Ghuanzhong plain (Zhang et

${ }^{*}$ Corresponding author. E-mail: txhong@hotmail.com or txhong@nwsuaf.edu.cn. Tel: 86-29-87082069 or 86-2987091600 al., 2008) threatening soil and considered crucial to enhance fertility, improve soil quality environmental quality. Residue returning in arable fields is and sustain the soil organic carbon (SOC) content on the other hand loss of SOC has adverse effects on physical, chemical and biological properties of soil and $\mathrm{CO}_{2}$ release (Kumar and Goh, 2003).

Guanzhong Plain is an important cereal production area accounting $19 \%$ of total land area with typical semihumid climate and prone to drought. Mostly crop lands in this area possess relatively low SOC contents due to long intensive cultivation coupled with less organic $C$ returns to soil (Zhang et al., 2008; Wang et al., 2008). Winter wheat and summer maize rotation annually is major cropping system of about 0.8 million hectares cultivated for past four decades. A great deal of straw is being 
Table 1. Microbial biomass nitrogen $\left(\mathrm{mg} \mathrm{kg}^{-1}\right)$ in soils with and without straw amended with microbial inoculants under different temperature regimes.

\begin{tabular}{|c|c|c|c|c|c|}
\hline \multirow{2}{*}{$\begin{array}{c}\text { Microbial } \\
\text { agent }\end{array}$} & \multicolumn{2}{|c|}{$S_{0}$} & \multicolumn{2}{|c|}{$\mathrm{S}_{1}$} & \multirow[b]{2}{*}{ Average } \\
\hline & $\mathrm{T}_{1}$ & $\mathrm{~T}_{2}$ & $\mathrm{~T}_{1}$ & $\mathrm{~T}_{2}$ & \\
\hline$P_{1}$ & $15.10 \mathrm{~cd}$ & $8.32 \mathrm{~d}$ & $56.26 \mathrm{ab}$ & $24.35 \mathrm{c}$ & $26.01 \mathrm{~A}$ \\
\hline$P_{2}$ & $22.11 \mathrm{~cd}$ & $14.99 \mathrm{~cd}$ & $47.27 \mathrm{~b}$ & $24.44 \mathrm{c}$ & $27.20 \mathrm{~A}$ \\
\hline$P_{3}$ & $18.73 \mathrm{~cd}$ & $11.90 \mathrm{~cd}$ & $69.85 \mathrm{a}$ & $18.95 \mathrm{~cd}$ & $29.86 \mathrm{~A}$ \\
\hline Average & $18.64 \mathrm{BC}$ & $11.73 \mathrm{C}$ & $57.79 \mathrm{~A}$ & $22.58 \mathrm{~B}$ & \\
\hline
\end{tabular}

Significant difference among treatments are indicated at $p<0.05$; significant difference among means are indicated at $p<0.01$

produced each year but only $15 \%$ is returned directly to soil (Han et al., 2002). Some are used for livestock, industry while rest is discarded or burnt causing serious environmental implication as $\mathrm{CO}_{2}$ emission. Field incorporation of straw after mechanized harvest is being promoted to enhance SOM levels, regulate C, supply nutrients, and improves soil quality and reduced $\mathrm{C}$ release to atmosphere (Abro et al., 2011).

Microbial interaction of specific microorganisms (cellulolytic and lignolytic) with soil and crop residue may be considered as an appropriate strategy for effective decomposition of added substrate. Fungi belonging to genus Aspergillus, Trichoderma, Phanerochaete and Coprinus are known to decompose, wheat straw (Gaind and Mathur, 2001). Bastian et al. (2009) reported that microbial succession on fresh organic residues incorporated will be dominated by copiotrophs and substrate quality declines with time. Use of microbial inoculants is being introduced to enhance rate of residue decomposition added to soil (Fang et al., 2005; Wang et al., 2003). Incorporation of straw into soil mixing of straw evolutes more $\mathrm{CO}_{2}$ as result of increased microbial activity (Potthoff et al., 2005; Chen et al., 2007). Less is known about this in our research area so it was our first aim to evaluate soil respiration $\left(\mathrm{CO}_{2}\right.$ evolution) with and without straw along with use of microbial inoculants under controlled lab simulation experiments. Microbial inoculants may also be affected by the increase or decrease in temperature for $\mathrm{CO}_{2}$ evolution from the soils with and without straw (Garnier et al., 2003). Tempera-ture is primary rate determinant and sensitivity of microbial processes and influences greatly the decomposition of SOC of added residues in soils (Kirschbaum, 2006; Wetterdest et al., 2009). Temperature drastically affects rates of $\mathrm{CO}_{2}$ release from soils added with residues (Niklinska et al., 1999).

Present study was therefore under-taken with the objectives a) to evaluate effectiveness of locally produced microbial inoculation product on $\mathrm{CO}_{2}$ (microbial respiretion) evolution in soils with and without wheat straw under different temperatures regimes. b) Subsequent effect of microbial inoculants in soils with and without wheat straw addition on soil properties as SOC, microbial biomass nitrogen (MBN) and soil inorganic nitrogen $\mathrm{NO}_{3}{ }^{-} \mathrm{N}, \mathrm{NH}_{4}{ }^{+}$ $\mathrm{N}$ (Table 1).

\section{MATERIAL AND METHODS}

\section{Preparation of soil and straw samples}

The soil used in this incubation study was collected on April, 2010 from Guanzhong Plain, Sanyuan County, Shaanxi Province, and Northwest China. Annual winter wheat and summer maize rotation is major cropping system in this area. The mean annual temperature and precipitation are approximately $13.6^{\circ} \mathrm{C}$ and 656 $\mathrm{mm}$, respectively. The soils were classified as Earth-cumuli Orthic Anthrosols according to Chinese Soil Taxonomy (ISSAS, 2001). The texture of soil was clayey loam with water holding capacity of $300 \mathrm{~kg}^{-1}, \mathrm{pH} 7.3$, organic carbon $9.2 \mathrm{~g} \cdot \mathrm{kg}^{-1}$, and total nitrogen 0.86 $\mathrm{g} \cdot \mathrm{kg}^{-1}$. Wheat ((Triticum aestivum) straw carbon was $43.3 \%$ and total nitrogen was $0.61 \%$. Soil samples were collected from surface horizon $(0-15 \mathrm{~cm})$ using soil auger. The soil was air dried and kept in plastic bags. Visible plant residues such as roots and leaves were removed by hand. The soil was ground and sieved through 2 $\mathrm{mm}$ sieve and then stored for 5 days at $4^{\circ} \mathrm{C}$. Wheat straw (including leaves and stems) was collected from the same field after the grain harvest and taken to the laboratory, washed with distilled water and dried at $70^{\circ} \mathrm{C}$. The wheat straw was cut into small pieces $(<1 \mathrm{~cm})$, ground and mixed with the soil samples for incubation.

\section{Experimental design and incubation procedure}

The experiment was set up with factorial design of 12 treatments with five replicates each; the 5th replicate was used as control (no straw addition) for every treatment. The ground straw was thoroughly mixed then transferred into PVC pots (height $11 \mathrm{~cm}$, inner dia. $250 \mathrm{~mm}$ ) for an equivalent of $125 \mathrm{~g}$ soil and $1.25 \mathrm{~g}$ wheat straw pot $^{-1}$. The amount of the straw added to soil ensured sufficient amounts of $\mathrm{C}$ for microbial respiration and was chosen to simulate field conditions of the $8 \mathrm{t} \mathrm{DM} \mathrm{ha}^{-1}$ incorporated into plough layer. Straw amended and microbially inoculated treatments will be described as and $\left(P_{1} S_{0} T_{1}, P_{1} S_{0} T_{2}, P_{2} S_{0} T_{1}, P_{2} S_{0} T_{2}, P_{3} S_{0} T_{1}, P_{3} S_{0} T_{2}\right)$, without straw and $\left(P_{1} S_{1} T_{1}, P_{1} S_{1} T_{2}, P_{2} S_{1} T_{1}, P_{2} S_{1} T_{2}, P_{3} S_{1} T_{1}, P_{3} S_{1} T_{2}\right)$ and with straw, in hereafter. Microbial inoculants levels $(P 1=0.1 \%$, $\mathrm{P} 2=0.2 \%, \mathrm{P} 3=0.3 \%$ ), Soils $\mathrm{S} 0=$ (soil without straw) $\mathrm{S} 1=$ (soil with straw), Temperature $-\mathrm{T}_{1}=15-^{\circ} \mathrm{C}, \mathrm{T}_{2}=25^{\circ} \mathrm{C}$ ).

Microbial inoculants used were obtained from locally produced in laboratory natural condition and got the inoculants culture. A solution culture of the inoculants was made on \% basis and was added to soils with and without straw. Nitrogen as $\left(\mathrm{NH}_{4}\right)_{2} \mathrm{SO}_{4}$ and phosphorus as $\mathrm{KH}_{2} \mathrm{PO}_{4}$ were uniformly applied to all pots as water solution to obtain adjusted moisture level. Samples were slowly wetted with calculated amount of deionized water to maintain approximately $85 \%$ moisture contents of water holding capacity. The pots were then kept in the two incubators at two 15 and $25^{\circ} \mathrm{C}$ constant temperatures for 73 days. Carbon dioxide evolution was regularly monitored using alkali absorption method, throughout experiment. 


\section{Analytical procedure}

\section{$\mathrm{CO}_{2}-\mathrm{C}$ determination}

The pots filled with a soil-straw mixture and $25 \mathrm{ml}$ vials containing $10 \mathrm{ml}$ of $1 \mathrm{M} \mathrm{NaOH}$ solution were placed on soil surface inside the pot to absorb $\mathrm{CO}_{2}$. Pots were covered with polyethylene sheets and incubated in the darkness at 20 and $25^{\circ} \mathrm{C}$ for 73 days. Excess $\mathrm{NaOH}$ was titrated with $0.2 \mathrm{M} \mathrm{HCl}$ after precipitating carbonates with $\mathrm{BaCl}_{2}$ using phenolphthalein as indicator and subtracted from the amount titrated in control without straw. All the pots were taken out and opened periodically, aerated for few minutes and soil water content was checked and adjusted by weighing then adding distilled water, to maintain moisture levels. The $\mathrm{CO}_{2}$ evolved was measured at $2,5,8,11,14,20,24,30,36,41$ and 73 th day of incubation. At the end of incubation samples were analyzed according to procedures.

\section{Soil organic carbon}

Soil organic carbon concentration was determined using dichromate $\mathrm{H}_{2} \mathrm{SO}_{4}-\mathrm{K}_{2} \mathrm{Cr}_{2} \mathrm{O}_{7}$ wet oxidation method of Walkley and Black (Nelson and Sommers, 1996).

\section{Microbial biomass $\mathbf{N}$}

Microbial biomass nitrogen was measured by chloroform fumigation extraction method (Brookes et al., 1985). A $40 \mathrm{~g}$ sample of moist soil was split into two portions shaken at $250 \mathrm{rev} \mathrm{min}^{-1}$ with $100 \mathrm{ml}$ $\mathrm{K}_{2} \mathrm{SO}_{4}$ and filtered through a folded filter paper. Organic $\mathrm{C}$ in $0.5 \mathrm{M}$ $\mathrm{K}_{2} \mathrm{SO}_{4}$ extracts was measured by Dohrman DC 80 . Soil microbial C was estimated from the relationship between organic carbon extracted from fumigated subtracted from non fumigated soil samples. The same relationship was applied for MBN in extracts.

\section{Soil inorganic $\mathrm{N}\left(\mathrm{NH}_{4}^{+}-\mathrm{N}, \mathrm{NO}_{3}^{-}-\mathrm{N}\right)$}

Inorganic $0.5 \mathrm{M} \mathrm{K}_{2} \mathrm{SO}_{4}$ extractable ${ }^{+}-\mathrm{N}_{\text {and }} \mathrm{NO}_{3}{ }^{-}-\mathrm{N}$ were determined colorimetry by (Automated chemistry analyzer) only in extracts form the non fumigated soil samples at 660 and $545 \mathrm{~nm}$, respectively.

\section{Statistical analysis}

Response of $\mathrm{CO}_{2}-\mathrm{C}$ evolution to microbial inoculants to soil under two temperatures was correlated to its effect on other parameters as SOC, SMBC, SMBN and inorganic N (Figure 1). Data were obtained as the mean and standard deviation (SD) and analyzed using 3-way analysis of variance (ANOVA) by the statistical package (SPSS 16.00 for windows) and Microsoft excel 2003. Differences in mean values were considered significant by Duncan's multiple range test $=\mathrm{P}<0.05$.

\section{RESULTS}

\section{Cumulative $\mathrm{CO}_{2-} \mathrm{C}$ evolution}

Table 2 describes the cumulative flux of $\mathrm{CO}_{2}-\mathrm{C}$ emission from soils with and without addition of wheat straw affected by application of microbial inoculants under two temperature regimes from all treatments. Statistical analysis showed that mixing of straw increased significantly cumulative $\mathrm{CO}_{2}-\mathrm{C}$ from all treatments.
Furthermore results revealed that addition of straw produced about $39.38 \%$ more $\mathrm{CO}_{2}$ compared to without addition of wheat straw. However in treatments with out straw lower temperature had $23.25 \%$ whereas in treatments with addition of straw only had $3.92 \%$ increases in $\mathrm{CO}_{2}-\mathrm{C}$. Although the application of microbial inoculants was not significant there was slight increase in the evolution of the $\mathrm{CO}_{2}$ with increase in the microbial inoculants applied. Generally, at lower temperature fairly higher cumulative $\mathrm{CO}_{2}-\mathrm{C}$ was emitted than at higher temperature.

The percent of carbon mineralized varied with $\mathrm{CO}_{2}$ emitted from all straw amended treatments. With straw returned treatments $58.24 \%$ was mineralized from straw organic C applied at lower temperature than $57.62 \%$ at higher temperature. While with all three $0.1,0.2,0.3 \%$ levels of microbial inoculants applied 57.32, 57.66, $57.84 \%$, respectively, soil carbon was mineralized to $\mathrm{CO}_{2}$ in 73 incubation days.

\section{Correlation of $\mathrm{CO}_{2}-\mathrm{C}$ emission with incubation time}

The cumulative $\mathrm{CO}_{2}-\mathrm{C}$ showed linear correlations with incubation time for both soils amended with and without addition of wheat straw with application of microbial inoculants under two different temperature levels. The $\mathrm{CO}_{2}-\mathrm{C}$ accumulation increased with incubation time in all treatments. Emissions from both, straw amended and without straw increased with increasing days of the incubation under both temperature regimes. $\mathrm{CO}_{2}$ flux varied significantly $(p<0.05)$ and considerably among all treatments (Figure 1).

\section{SOC}

Table 3 describes the accumulation of SOC in the soil samples amended with and without wheat straw treated with microbial inoculants under two temperature regimes in all 12 treatments. Returning wheat straw to soil significantly $(p<0.05)$ increased SOC levels in soils in comparison to no addition of straw. SOC remained non significant in treatments without addition of straw but was significant where the straw was applied under different temperatures. Microbial inoculants with lower temperature generally increased SOC levels. On average in treatments with no addition of straw lower temperature had $3.99 \%$ whereas in treatments with addition of straw had $6.66 \%$ increases over higher temperature. However there was slight increase found with increase of microbial inoculants levels 1, 2 and $3 \%$ used.

\section{Soil microbial biomass nitrogen}

Similar to MBC, different microbial additions significantly influenced the MBN. Comparing with control, addition of 

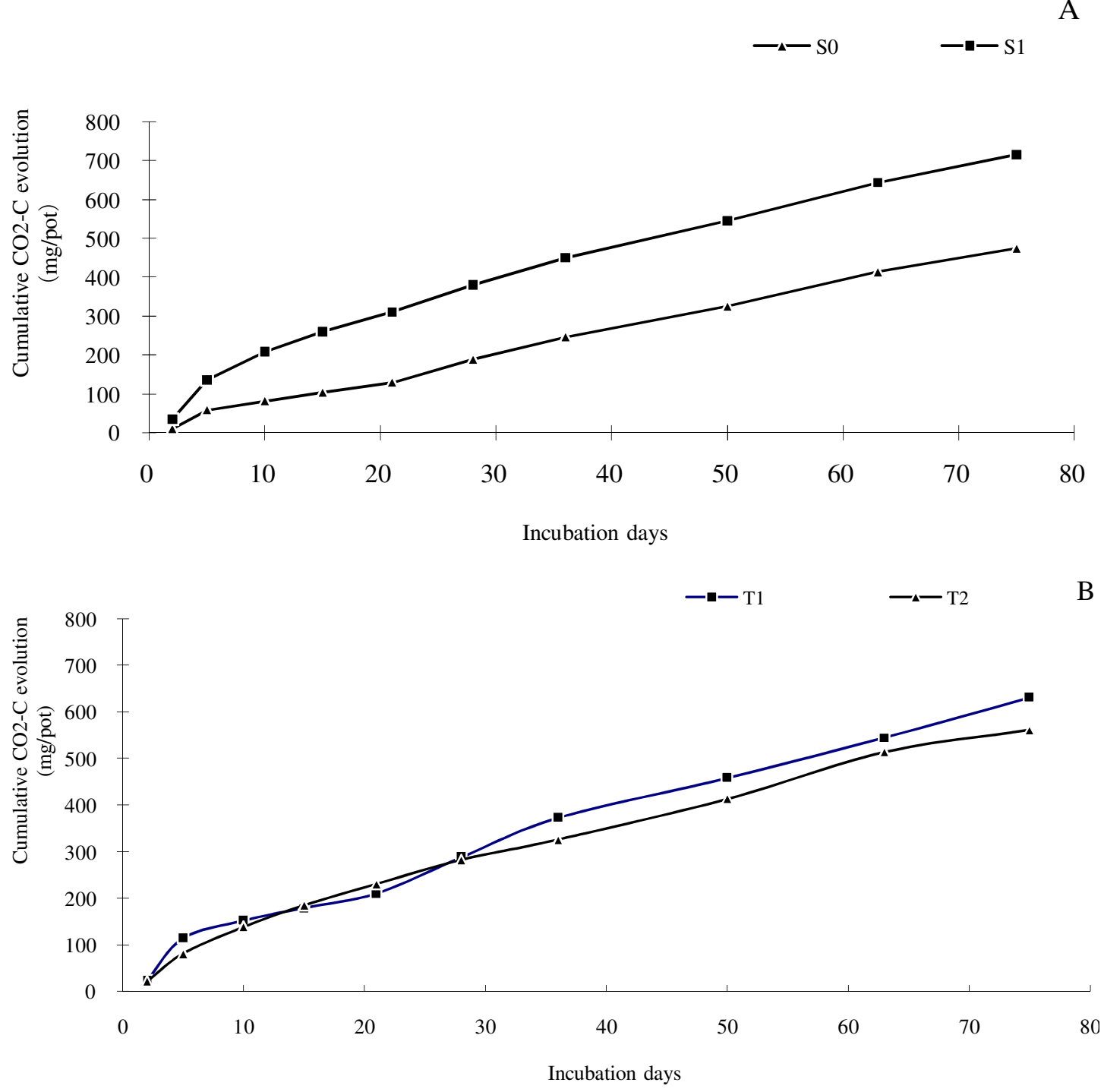

Figure 1. Response of soils (a) with and without straw and (b) temperature dependence of $\mathrm{CO}_{2}-\mathrm{C}$ evolution to the days of incubated for 73 days.

Table 2. Cumulative $\mathrm{CO}_{2}-\mathrm{C}\left(\mathrm{mg} \mathrm{pot}^{-1}\right)$ emission from soils with and without straw amended with microbial inoculants under different temperature regimes.

\begin{tabular}{ccccccc}
\hline Microbial & \multicolumn{2}{c}{$\mathbf{S}_{0}$} & & \multicolumn{2}{c}{$\mathbf{S}_{1}$} & \\
\cline { 2 - 4 } \cline { 5 - 6 } agent & $\mathbf{T}_{1}$ & $\mathbf{T}_{2}$ & & $\mathbf{T}_{1}$ & $\mathbf{T}_{2}$ & Average \\
\hline $\mathrm{P}_{1}$ & $423 \mathrm{C}$ & $331 \mathrm{~d}$ & & $580 \mathrm{a}$ & $562 \mathrm{~b}$ & $474 \mathrm{~A}$ \\
$\mathrm{P}_{2}$ & $431 \mathrm{c}$ & $327 \mathrm{~d}$ & & $577 \mathrm{ab}$ & $571 \mathrm{ab}$ & $477 \mathrm{~A}$ \\
$\mathrm{P}_{3}$ & $436 \mathrm{C}$ & $332 \mathrm{~d}$ & & $579 \mathrm{a}$ & $569 \mathrm{ab}$ & $479 \mathrm{~A}$ \\
Average & $430 \mathrm{C}$ & $330 \mathrm{D}$ & & 579 & 567 & \\
\hline
\end{tabular}

*Significant difference among treatments is indicated at $p<0.05$ : significant difference among means is indicated at $p<0.01$.

wheat straw brought significant increase in MBN. Straw addition brought about $37.83 \%$ increases in MBN. Almost similar trends were observed for production of MBN compared to MBC. It was observed that both straw addition with use of microbial agent significantly affected
MBN but under lower temperature regimes. On average addition of straw to soil brought about $37.78 \%$ increase in MBN while in treatments without straw $37.07 \%$ increase at higher temperature where as in treatments with addition of straw there was $39.07 \%$ increase at lower than 
Table 3. Soil Organic Carbon $\mathrm{g} \mathrm{kg}^{-1}$ accumulated in soils with and without straw amended with microbial inoculants under different temperature regimes.

\begin{tabular}{|c|c|c|c|c|c|}
\hline \multirow{2}{*}{ Microbial agent } & \multicolumn{2}{|c|}{$\mathrm{S}_{0}$} & \multicolumn{2}{|c|}{$S_{1}$} & \multirow[b]{2}{*}{ Averaqe } \\
\hline & $T_{1}$ & $T_{2}$ & $T_{1}$ & $T_{2}$ & \\
\hline $\mathrm{P}_{1}$ & $13.71 \mathrm{ab}$ & $12.70 \mathrm{cde}$ & $13.76 \mathrm{ab}$ & $12.49 \mathrm{e}$ & $13.16 \mathrm{~A}$ \\
\hline$P_{2}$ & $12.80 \mathrm{cde}$ & $12.92 \mathrm{de}$ & $14.38 \mathrm{a}$ & $12.45 \mathrm{e}$ & $13.14 \mathrm{~A}$ \\
\hline$P_{3}$ & $13.30 \mathrm{bc}$ & $12.61 \mathrm{de}$ & $13.27 \mathrm{bcd}$ & $13.74 \mathrm{ab}$ & $13.23 \mathrm{~A}$ \\
\hline Average & 13.27 AB & $12.74 \mathrm{~B}$ & $13.81 \mathrm{~A}$ & 12.89 & \\
\hline
\end{tabular}

Significant difference among treatments are indicated at $p<0.05$; significant difference among means are indicated at $p<0.01$

higher temperature. However there was slight increase in MBN with addition of microbial inoculants.

\section{Soil Inorganic $\mathrm{N}\left(\mathrm{NH}_{4}-\mathrm{N}, \mathrm{NO}_{3}-\mathrm{N}\right)$}

Generally, values of the controls for $\mathrm{NH}_{4}$ and $\mathrm{NO}_{3}$ were relatively higher in our study; probably due to $\mathrm{N}$ immobilization in samples Figure 2 depicts the $\mathrm{NO}_{3}$ fluctuations in with and without straw amended treatments. Results revealed that higher concentration was found in samples without wheat straw whereas less was observed in straw amended treatments. Higher temperature $25^{\circ} \mathrm{C}$ produced more $\mathrm{NO}_{3}$ than lower $15^{\circ} \mathrm{C}$ temperature. Contrary to that, $\mathrm{NH}_{4}{ }^{+}-\mathrm{N}$ depicted different picture as treatments without addition of straw generated less $\mathrm{NH}_{4}{ }^{-} \mathrm{N}$ than with addition of straw. Values were higher at lower temperature than at higher temperature. However microbial inoculant has low effect on inorganic $\mathrm{N}$ concentration in samples with and without straw amended treatments. $\mathrm{NO}_{3}{ }^{-} \mathrm{N}$ remained significant with changes in temperature whereas $\mathrm{NH}_{4}-\mathrm{N}$ was not significant with temperature but significant in terms of with and without addition of straw.

\section{DISCUSSION}

\section{Effect of microbial product on $\mathrm{CO}_{2}$ evolution in soils with and without straw under temperatures}

\section{Cumulative evolution $\mathrm{CO}_{2}$}

In accordance with findings of Potthoff et al. (2005), the mixing of the straw with soil increased $40 \%$ the cumulitive $\mathrm{CO}_{2}-\mathrm{C}$ production compared in treatments with no addition of straw. It was observed that in soil samples without straw increased about $7-9 \%$ increase in cumulitive $\mathrm{CO}_{2}$ evolution in incubation. Magan et al. (2002) incubated wheat straw with seven different inoculants in laboratory and revealed that all inoculants successfully established to different extents on the straw, none markedly improved decomposition in either wet or dry soil when compared with non-treated straw. In general, whereas all inoculants levels successfully established to different extents on the straw, none significantly improved
SOC mineralization in either soils with or without straw addition. The failure to respond to inoculation could in part be due to the high natural $C$. butyricum populations present on the straw used in agreement with results found by Wetterstedt et al. (2009).

This study revealed that initially rate of straw decomposition was higher at $25^{\circ} \mathrm{C}$ up to one month than leveled off with $15^{\circ} \mathrm{C}$, while finally it was higher at $15^{\circ} \mathrm{C}$ however slightly increasing with increasing levels of microbial inoculants. Straw decomposition showed less sensitivity to fluctuating temperature may be substrate quality or microbial inoculant is a factor to be considered. Present study revealed that in treatments and with out straw inoculated with microbial inoculums cumulative $\mathrm{CO}_{2}$ emission was higher at lower than higher temperature. These results are in accordance with the results found by (Wetterstedt et al., 2009) who reported that more cumulative flux of $\mathrm{CO}_{2}-\mathrm{C}$ was evolved from decomposing straw treatments incubated under 15 than $25^{\circ} \mathrm{C}$. However (Bastian et al., 2009) incubated straw and reported that microorganisms both bacteria and fungi involved in decomposition of wheat straw are more sensitive to low temperatures.

\section{Effect of straw incorporation on soil organic carbon (SOC) and microbial biomass under different temperatures}

Microbial inoculants have some effect on enhancing microbial activity. Crop residues are one of the main sources of SOC and returning straw has obvious effects on soil carbon transformation and storage. The addition of straw with soil slightly increased the SOC content in the soil probably because the wheat straw contains organic carbon about $40 \%$ that is why straw enhanced SOC. The amount of microbial inoculants may have contributed little bit more for SOC accumulation along with uniform application of N P in this incubation study. The increase in levels $\left(P_{3}\right)$ of microbial inoculants generated fairly higher SOC compared to first two levels. The difference was significant under lower than the higher temperature.

This implies that higher temperature accelerates loss of SOC from soils whereas lower temperature keeps the 


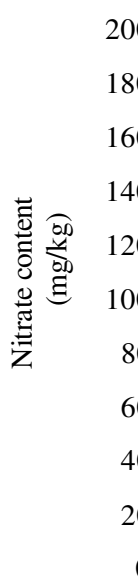

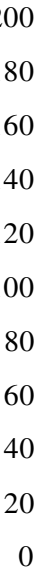

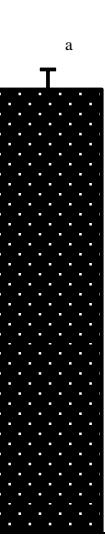

SO

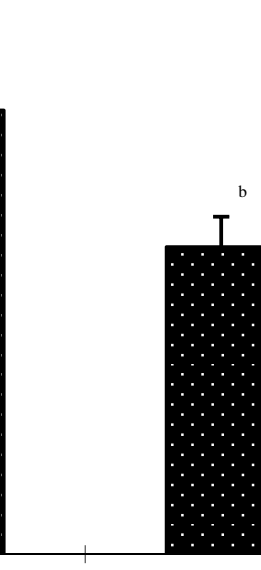

S1
A

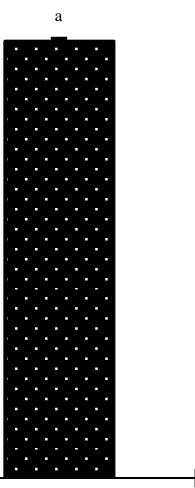

$\mathrm{T} 2$

Straw and Temperature Levels

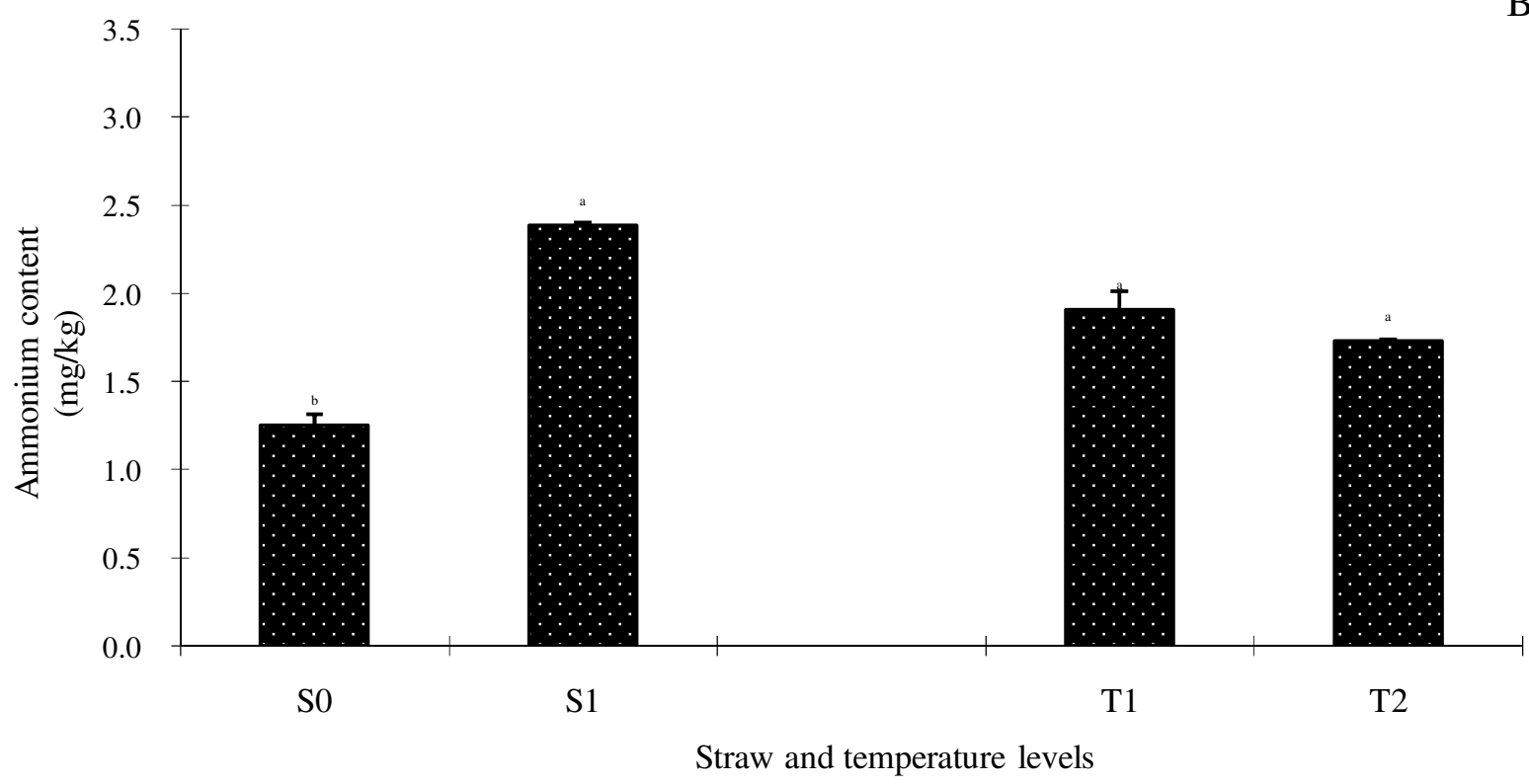

Figure 2. (a) Ammonium and (b) nitrate accumulation in soils with and without straw amended with microbial inoculants under different temperature regimes.

evolution rates low. These results were in agreement with results found by Gaind (2007) who stated that soil organic carbon were found to be improved significantly in wheat straw + N, P, and microbial inoculants. Chen et al. (2007) while incubating straw revealed that straw mixing enhanced the SOC content of soils incubated with straw under controlled conditions. Thus, returning straw to soil is expected to become one of the best ways to improve soil fertility and crop yield, hence rates of straw returned to soil must be enhanced. High $\mathrm{CO}_{2}$ emission in recent years has become a matter of great concern to the global community based on geological and ecological, studies. Addition of wheat straw along with microbial inoculants application can significantly increase SOC content and reduce $\mathrm{CO}_{2}$ emissions to atmosphere. After the decomposition of straw, $\mathrm{C}$ emission from decomposition will be reduced. So adding straw into soil has obvious effect on significant increase in SOC levels under lower temperature and microbial inoculants application.

Microbial biomass nitrogen (MBN) was significantly increased by mixing of straw into soil. The microbial inoculants had little effect on the MBN and third level yielded little bit more than 2nd and first levels. Gaind (2007) revealed that returning straw in combination with microbial inoculation ( $T$. reese $I$ ) improved microbial biomass and dehydrogenese and humus content. The lower temperature almost produced more MBN than at higher temperature probably as all the microbial 
processes are optimum at favorable temperature. Slight increase was observed due to increasing levels of microbial inoculants on soil parameters may be due to production of hydrophobin. In line with the findings of Potthoff et al. (2005), this research showed that returning of wheat straw to soil greatly improved soil microbial conditions. Oliver and William (2000) reported that microbial biomass significantly increased with use of straw into soil under differetn temepratues and moistures.

$\mathrm{Li}$ et al. (2006) reported that microbial properties were enhanced by mixing of straw with soil. $\mathrm{N}$ addition at different moisture levels had little effect on MBN, however, straw mixing caused significant increase in soil microbial biomass nitrogen content. Returning straw to soil plays an important role in improving soil quality, productivity and achieving sustainable utilization of soil. So direct returning of straw should be promoted in plain for enhanced microbial biomass.

\section{Effect of straw mixing, temperature and microbial inoculants on soil inorganic $\mathrm{N}\left(\mathrm{NH}_{4}{ }^{+}-\mathrm{N}, \mathrm{NO}_{3}{ }^{-}-\mathrm{N}\right)$}

Both $\mathrm{NO}_{3}{ }^{-} \mathrm{N}$ and $\mathrm{NH}_{4}{ }^{+}-\mathrm{N}$ were generally lower in treatments amended with straw compared to treatment without straw, which implied that high $\mathrm{C} / \mathrm{N}$ ratios of wheat straw addition increased $\mathrm{N}$ immobilization; this may coincide with observed changes in $\mathrm{MBN}$. $\mathrm{NH}_{4}{ }_{4} \mathrm{~N}$ content rapidly increased during the initial period which might be attributed to $\mathrm{NH}_{4}{ }^{-} \mathrm{N}$ desorption and organic $\mathrm{N}$ mineralization (Lou et al., 2007). Very little ammonium $\mathrm{N}$ was recovered, possibly because the ammonium was preferably taken up by soil microbes or it had been microbially consumed or converted to both microbial consumption of $\mathrm{N}$ and immobilization in the early period of decomposition led to lower recovery of $\mathrm{NH}_{4}{ }^{+} \mathrm{N}$. Similar results were found and attributed to microbial consumption and strong $\mathrm{N}$ immobilization after incubation of soil with added wheat straw (Duong et al., 2009). More ammonium $\mathrm{N}$ was produced at low temperature in treatments amended with wheat straw in our experiment and results are confirmed by the results found by (Wetterstedt et al., 2009) on wheat straw decomposition at different temperatures.

On the contrarily $\mathrm{NO}_{3}{ }^{-} \mathrm{N}$ presented an opposite picture in both soils amended with and without wheat straw under different temperatures. More inorganic $\mathrm{N}$ had accumulated in $5^{\circ} \mathrm{C}$ than in $15,25^{\circ} \mathrm{C}$ microsms at same cumulative respiration. One explanation might be that more $\mathrm{N}$ was used for building up of microbial biomass instead of being mineralized (Wetterstedt et al., 2009). $\mathrm{NO}_{3}{ }^{-} \mathrm{N}$ displayed a different pattern and it was observed that values were higher in soils with no straw addition compared with straw amended treatments. More $\mathrm{NO}_{3}$ accumulated in treatments under higher temperature in comparison to lower temperatures in present incubation study. Higher soil $\mathrm{NO}_{3}-\mathrm{N}$ was recovered and was positively correlated with increasing temperatures.

\section{Conclusion}

Returning wheat straw into soil along with microbial inoculants application under optimum temperature will be effective measure for improvement of SOC, microbial biomass and soil quality. Wheat straw addition will result in multifarious benefits as valuable utilization of straw, low input of chemical fertilizer and improved soil health.

\section{ACKNOWLEDGEMENT}

This study was financially supported by National Natural Sciences Foundation of China (40971179, 31071863) Innovative Research Team Program of Northwest A\&F University in 2010

\section{REFERENCES}

Abro SA, Tian XH, You DH, Wang XD (2011). Emission of carbon dioxide influenced by nitrogen and water levels from soil incubated straw. Plant Soil Envir. J., 57: 295-300.

Bastian F, Bouziri L, Nicolardot B, Lionel R (2009). Impact of wheat straw decomposition on successional patterns of soil microbial community structure. Soil Biol. Biochem., 41: 262-275.

Brookes PC, Landman A, Pruden G, Jenkinson DS (1985). Chloroform fumigation and the release of soil-nitrogen-a rapid direct extraction method to measure microbial biomass nitrogen in soil. Soil Biol. Biochem., 17: 837-842.

Chen H, Norbert B, Karl S, Yakov K (2007). Effect of nitrogen and intensive mixing on decomposition of labeled maize (Zea. mays L) residue in soils of different land use types. Soil Till. Res., 96: 114-123.

Dalia F, Grazina K (2008). The influence of soil organic carbon, moisture and temperature on soil surface $\mathrm{CO}_{2}$ emission in the $10^{\text {th }}$ year of different tillage-fertilization management. Zemd. Agri., 4: 29-45.

Duong TT, Baumann K, Marshner P (2009). Frequent addition of wheat straw to soil enhances carbon mineralization rates. Soil Biol. Biochem., 41: 1475-1482.

Fang C, Smith P, Smith JU, Moncrieff JB (2005). Incorporating microorganisms as decomposers into models to simulate soil organic matter decomposition. Geoderma, 129: 139-146.

Gaind S, Mathur RS (2001). Influence of in situ incorporation of organic waste on chemical and biochemical properties of soil under ricewheat cropping system. Ecol. Env. Cons., 7: 269-272.

Gaind SL (2007). Chemical and biological properties of wheat soil in response to paddy straw incorporation and its biodegradation by fungal inoculants. Biodegradation, 18: 495-503.

Garnier P, Neel C, Aita C, Recous S, Lafolie F, Mary B (2003). Modelling carbon and nitrogen dynamics in bare soil with and without straw incorporation. Eur. J. Soil Sci., 54: 555-568.

Han LJ, Yan Q, yang LX, Hu JY (2002). Straw Rresources and their utilization in China. Trans. CSAE., 18: 87-91.

Institute of Soil Science of Academia Sinica (ISSAS). (2001). Chinese Soil Taxonomy. Science Press, Beijing, New York. p. 87

Kirschbaum MUF (2006). The temperature dependence of organicmatter decomposition- Still a topic of debate. Soil Biol. Biochem., 48: 21-51

Kumar K, Goh KM (2003). Nitrogen release from crop residues and organic amendments as affected by biochemical composition. Commun. Soil Sci. Plant Anna., 34: 2441-2460.

Lal R (2004). Soil carbon sequestration to mitigate climate change, Geoderma, 7: 123: 1-22.

Lou Y, Ren LX, Zhou P, Zhang TL, Kazuyuki I (2007). Effect of Rice Residues on Carbon Dioxide and Nitrous Oxide Emissions from a Paddy Soil of Subtropical China. Water Air Soil Pollut., 178: 157-168.

Potthoff M, Dyckmans J, Flessa H, Muhs A (2005). Dynamics of maize leaf straw mineralization as affected by the presence of soil and 
availability of nitrogen. Soil Biol. Biochem., 37:1259-1266.

Nelson DW, Sommers LE (1996). Total carbon, organic carbon and organic matter. In: Spark.D.L, (ED) Methods of Soil Analysis. Part 3. Chemical Methods. Wisconsin, USA., 75: 961-1010.

Magan N, Hand P, Kirkwood IA Lynch JM (2002). Establishment of microbial inoculation on decomposing wheat straw in soil of different water contents. Soil Biol. Biochem., 14:37-43.

Niklinska M, Maryanski M, Laskowski R (1999). Effect of temperature on humus respiration rate and nitrogen mineralization: Implications for global climate change. Biogeochemistry, 44: 239-257.

Oliver CD, William RH (2000). Decomposition of rice straw and microbial carbon use efficiency under different soil temperature and moistures. Soil Biol. Biochem., 32: 1773-1785.

Vanhala P, Karhu K, Tuomi M, Sonninen E, Jungner H, Fritze H, Liski $J$ (2007). Old soil carbon is more temperature sensitive than the young in an agricultural field. Soil Biol. Biochem., 39: 2967-2970.
Wang WJ, Dalal RC, Moody PW, Smith CJ (2003). Relationship of soil respiration to microbial biomass, substrate availability and clay content. Soil Biol. Biochem., 35: 273-284.

Wang LG, Qiu JJ, Tang HJ, Hu L, Li CS, Eric VR (2008). Modeling Soil organic carbon dynamics in the major agricultural regions of China. Geoderma, 147: 47-55.

Wang YQ, Zhang XC, Zhang JL, Li SJ (2009). Special variability of Soil organic carbon in water shed on Loess Pleatu. Pedosphere, 4: 486-495.

Wetterstedt JÅM, Persson T, Ågren GI (2009). Temperature sensitivity and substrate quality in soil organic matter decomposition: results of an incubation study with three substrates. Glob Change Biol., doi:10.1111/ j.1365e2486.2009.02112.x.

Zhang QZ, Yang ZL, Wu WL (2008). Role of crop residue management in sustainable agricultural development in the North China Plain. J. Sust. Agric., 32: 137-148. 